\title{
О.С. Власова
}

Харківський національний університет міського господарства імені О.М. Бекетова, Украӥна

\section{ТРАНСФЕРТНІ ЦІНИ: ПЕРЕДУМОВИ ВИКОРИСТАННЯ В УПРАВЛІНСЬКОМУ ОБЛІКУ ТА ПОДАТКОВОМУ АДМІНІСТРУВАННІ}

У статті проаналізовано проблеми прийняття рішення щзодо застосування трансферних ціін для обслуговування внутрішньо-групового обігу корпорацій з розгалуженою інтегрованою структурою. Запропонований комплексний погляд на вказану проблему з огляду на практику господарювання. Систематизовані переваги та недоліки управлінських рішень про використання трансферних цін, а також механізм їх контролю в рамках податкового адміністрування міжнародного бізнесу.

Ключові слова: трансферне ціноутворення, управлінський облік, податковий контроль, внутрішньогосподарські операції, міжнародний бізнес.

\section{Постановка проблеми}

Становлення i розвиток конкурентоспроможного бізнесу у вітчизняній економіці спирається на такі великі інтегровані формування, як корпорації. Ринкові умови висувають вимоги по ефективному управлінню в цих господарюючих суб'єктах, яке неможливо без наявності у керівництва своєчасної та достовірної інформації для прийняття оптимальних управлінських рішень. Необхідність отримання зазначеної інформації створює якісно нову ситуацію, пред’являє особливі вимоги до системи внутрішньо-корпоративного ціноутворення. Економічна самостійність організацій в рамках єдиного господарського механізму передбачає застосування нових підходів до формування внутрішньо-корпоративних (трансфертних) цін. Також питання трансфертного ціноутворення на сьогодні виходять на перші місця в рейтингу актуальних проблем податкового адміністрування не лише в Україні, а й у світі в цілому. Це пов'язано 3 необхідністю здійснення податкового контролю за забезпеченням рівності таких цін між пов'язаними та незалежними особами в рамках міжнародного бізнесу як заходу протидії розмиванню бази оподаткування та виведенню прибутку з-під оподаткування. Зважаючи на це, стає зрозумілою значна увага до механізмів трансфертного ціноутворення в рамках управлінського обліку та податковому адмініструванні.

\section{Аналіз останніх досліджень і публікацій}

Всю сукупність наукових досліджень іноземних та вітчизняних науковців 3 питань трансферне ціноутворення пов'язують 3 управлінським обліком або податковим контролем. Це $\epsilon$ обгрунтованим оскільки саме в цих напрямках здійснюється застосування трансферних цін. Виходячи 3 цього розділимо проаналізований наукових добуток на два блоки.

Перший блок передбачає розгляд трансферних цін як елементу управлінського обліку, спрямованого на формування обліково-аналітичної інформації про внутрішньо фірмові транзакції. При цьому проведений аналіз дозволив зробити додаткову проміжну градацію виходячи 3 визначених науковцями завдань, які реалізуються при впровадження трансферних цін.

Так, перша група авторів, до яких можна віднести Атамаса П.Й. [1], Вахрушину М.А. [2], Алборова Р.А. [3], Волкова А.В. [4], Симона Г. [5], розглядає трансферну ціну, як спосіб відстеження приросту доданої вартості на протязі всього виробничого циклу в розрізі окремих центрів відповідальності.

Друга група авторів, досліджувала трансферні ціни як ціни, що формуються умовно виходячи 3 внутрішньої управлінської політики або стратегії, яка діє в компанії, навіть без застосування калькулювання. У цьому випадку такі ціни розглядаються як елемент бюджетування центрів відповідальності. Наприклад, Палій В.Ф [6]. відмічав, що трансферні ціни виконують тільки планово-облікові функції та не впливають на фінансове положення організації у цілому. Також аналогічні наукові погляди виражали Радецька Л.П., Овод Л.В. [7, с. 185], Мюллер Г. [8].

В третю групу включено підходи, які формулювалися Дж. Доунсом та Гудманом Дж. Єліотом [9]. Ці автори відмічали, що можливість формування трансферних цін тільки у випадку існування єдиного центру управління, який би відповідав за максимізацію прибутку. При цьому передбачалося, що встановлення такої ціни повинно здійснюватися виходячи 3 комерційних та 
фінансових умов угод в рамках єдиної бізнес-моделі компанії або холдингу незалежно від їі відповідності ринковим показникам.

Четвертий напрямок формують наукові підходи, відмінною рисою яких $є$ розгляд трансферної ціни як способу аналізу взаємовідносин центрів прибутку, який впливає на оцінку ефективності їхньої діяльності. Представниками такої позиції серед західних економістів є Р. Ентоні і Дж. Рис [10], К. Друрі [11] та ін.

До другого блоку наукових підходів можна віднести наукові та практичні дослідження щодо встановлення трансферної ціни в угодах 3 передачі товарів, технологій або послуг в рамках транснаціональних корпораціях та холдингів. Так американські вчені Р. Іден, Дж. Лорен [12] визначали трансфертну ціну як ціну, що застосовується між взаємопов'язаними суб'єктами господарювання, що входять до однієї корпорації, виходячи 3 комерційних та фінансових умов, відмінних від умов, які застосовуються між незалежними особами. У цьому випадку, трансфертна ціна трактується як оптимізаційний механізм мінімізації податкових платежів в рамках міжнародного бізнесу, що передбачає трансфер доходної частини за угодами на користь юридичних осіб зі зниженим податковим навантаженням або осіб, які є пов'язаними з постачальником. Зазвичай, у цьому випадку, трансфертні ціни розглядаються як оптові, що застосовуються всередині однієї групи компаній. Слід зазначити, що вже довгий час цей напрямок досліджень $є$ особливо популярним у дослідників. Оскільки, як відмічав Л. Шеппард (США) трансферне ціноутворення є найгострішим питанням серед проблем міжнародного оподаткування [13], а Г. Хамакерс (Нідерланди) вважає, що 3 фінансової точки зору трансферне ціноутворення $\epsilon$ найбільш важливим податковим інститутом у світі [14]. Вітчизняні фахівці також не залишилися осторонь цього тренду, про що свідчить велика кількість науково-практичних робіт 3 цієї теми, зокрема: Мішина М.О. [15], Жукової О.В. [16], Карпенко I.В. [17], Луценко І.С. [18], Коблянської O.I. [19].

Хоча, як наведено вище, питання трансферного ціноутворення досить активно досліджуються, але й сьогодні залишаються невирішеними багато питань, зокрема щодо застосування трансферних цін в єдиній обліково-аналітичній системі для вирішення 3 одного боку питань реалізації стратегічних напрямків та інноваційного розвитку підприємств, а 3 іншого відповідності вимогам глобального та українського податкового законодавства.

Метою дослідження є пошук відповіді на питання щодо передумов застосування цього обліково-аналітичного інструмента для обслуговування внутрішньо-групового обігу корпорацій, а також сфера та регламентація його застосування для податкового адміністрування.

\section{Виклад основного матеріалу дослідження}

Поточна економічна ситуація, що склалася в нинішній реальності, спотвореній негативним впливом пандемії COVID-19, виражається, перш за все, падінням або відсутністю позитивних фінансових результатів господарюючих суб'єктів і значним падінням платоспроможного попиту. Для трансфертного ціноутворення це виражається в зміні практики застосування і нових теоретичних аспектах застосування методів трансфертного ціноутворення 3 урахуванням негативної картини економічної реальності. Виділимо негативні наслідки для практики застосування трансфертного ціноутворення. До них відносяться:

- диспропорції обсягів між виробництвом i дистрибуцією;

- зміна масштабу діяльності (скорочення облікової чисельності персоналу, операційних витрат, зменшення виробничих потужностей тощо);

- різкі зміни в розмірності дебіторської і кредиторської заборгованості;

- невідповідність рівня запасів щодо аналогічних періодів минулих років;

- згортання частини виробничих, логістичних операцій;

- невідповідність винагороди ліцензіата i співвіднесення винагороди на результат господарської діяльності у вигляді виручки для групи взаємопов'язаних осіб.

Таким чином, на сьогодні виникають нові тренди теорії і практики застосування трансфертного ціноутворення, що потрібно враховувати як в управлінському обліку під час формування прогнозних показників (на 2-3 роки), так й податкових розрахунках щодо зовнішньоекономічних операцій між взаємопов'язаними особами або 3 підприємствами зі зниженим податковим навантаженням.

Необхідність застосування механізму трансфертних цін в управлінському обліку з'явилася внаслідок сучасної тенденції 3 децентралізації управління, коли підприємства почали ділитися на структурні підрозділи, що відповідають за виконання конкретного функціонального переліку.

Передумовою цього стало прагнення топменеджменту прискорити процес виробництва, пришвидшити обіг власного капіталу підприємства, a також максимізації прибутку. Це призвело до створення корпорацій 3 кінцевим технологічним циклом при якому всі функції виконують відповідні підрозділи (юридичні особи) починаючи з моменту отримання сировини і закінчуючи перетворенням в 
готову продукцію 3 подальшим доведенням до споживача, без залучення посередників. У такій ситуації менеджмент великих корпорацій почав вести пошук нових способів ефективного управління, здатного зберегти єдність корпорації. Ним стало застосування в рамках внутрішньофірмових розрахунків трансферних цін.

До переваг, які можуть отримати корпорації від запровадження трансферних цін, відносяться:

- сприяння концентрації розрізнених ресурсів корпорації в єдине ціле за допомогою управління рухом фінансових потоків;

- дозволяє отримати корпораціям конкурентні переваги за рахунок набуття можливості здійснювати маркетингові заходи, проводити науково-дослідні та дослідно-конструкторські розробки без залучення сторонніх осіб, а значить за мінімальною вартістю;

- створює передумови для об'єднання інформації, що міститься в системах управлінського обліку окремих організацій, в єдину систему обліково-аналітичну систему корпорації;

- дозволяє виключити спотворення собівартості продукції (робіт, послуг) за рахунок усунення повторного обліку витрат щодо взаємних поставок (послуг), що дає можливість об'єктивно уточнювати, за необхідності, змінні та постійні витрати, маржинальний доход в рамках бюджетування;

- допомога у вирішенні завдання щодо оцінки результатів діяльності центрів фінансової відповідальності, які надають один одному взаємні послуги, а значить, сприяють зростанню мотивації їх персоналу;

- створення умов для зростання економічної відповідальності підрозділів, які застосовують трансферне ціноутворення, чого бракує при повній відмові від подібної практики.

Однак, приймаючи рішення про застосування такого інструменту внутрішнього ціноутворення, треба мати на увазі й застережливі моменти:

- через своє штучне походження трансферні ціни здатні призводити до спотворення справжнього розміру витрат підрозділу, оскільки існує великий ризик помилок при їх розрахунку;

- при некоректному використанні або відсутності методологічного базису, трансферні ціни здатні породжувати конфлікт інтересів взаємодіючих між собою підрозділів і навіть їх відособленість, так званий «дивізіональний егоїзм»;

- розрахунок трансфертних цін сам по собі вимагає часу та грошей, що особливо актуально в умовах високої інфляції і регулярного перегляду нормативів, тарифів і ціни на ресурси;

- внаслідок необхідності додаткового часу, що потрібен для узгодження трансферних цін, особливо в складних ієрархічних структурах, де право прийняття цінових рішень не делеговане нижнім рівнями управління, значно уповільнюється процес виконання замовлень;

- в залежності від методів розрахунку трансферних цін може знизитися мотивація одних структурних підрозділів і обгрунтовуватися низька ефективність інших підрозділів.

3 огляду на це, стає зрозумілим, що рішення багатьох корпорацій не застосовувати трансферні ціни в рамках управлінського обліку. Хоча за умови більш грунтовного підходу до розробки та впровадження методології формування трансферних цін 3 урахуванням особливостей корпоративної бізнесмоделі, застосування трансферного ціноутворення може перетворити корпорацію зі складною ієрархією управління в узгоджену i керовану децентралізовану структуру.

На відміну від трансферного ціноутворення, здійснюваного в рамках управлінського обліку, застосування таких цін між формально незалежними партнерами по бізнесу, також дозволяє вирішити низку специфічних завдань. До їх числа відносяться:

- оптимізація оподаткування та митних платежів в масштабі всієї інтегрованої структури корпорації;

- експорт капіталу (виведення капіталу 3 країни);

- переміщення фінансових потоків між підрозділами компанії, в тому числі 3 метою подальшого продажу конкретної структурної одиниці і ऑï виведення зі складу холдингу або корпорації;

- зниження економічних і політичних ризиків за рахунок акумулювання прибутку в регіонах 3 більш низьким рівнем таких ризиків;

- податкова економія, в т.ч. акумулювання прибутку в низькоподаткових юрисдикціях, в збиткових компаніях тощо.

Тобто, з цього боку трансферні ціни постають способом мінімізації податкового тягаря, розмивання податкової бази та виводу прибутку зпід оподаткування через таке маніпулювання цінами.

Слід зазначити, що ця проблема вже довгий час (близько сорока років) бентежить економічно розвинені держави, які проводять цілеспрямовану роботу щодо зниження негативного впливу на державні бюджети такого специфічного застосування трансферних цін. Зрозуміло, що в рамках окремих країн, нівелювання негативного впливу таких цін повністю зробити неможливо. Тому на сьогодні ця проблема набула нового глобального масштабу, для вирішення якої були створені відповідні світові та континентальні організації. 
Основною з них є Організація економічного співробітництва та розвитку (ОЕСР), яка створена 3 метою консолідації зусиль урядів задля ефективного протистояння економічним, соціальним та екологічним проблемам, в перелік яких віднесено й дослідження, розробка та вдосконалення регулювання проблеми трансфертного ціноутворення на світовому рівні. Ця організація станом на грудень 2020 р. нараховує 37 держав [20], в тому числі більшість держав - членів $\mathrm{CC}$, а також економічно розвинених країн.

Україна не є членом ОЕСР, хоча й активно співпрацює 3 цією організацією в статусі асоційованого члена в рамках Глобального форуму OECP 3 прозорості та обміну інформацією для податкових цілей. В рамках цього Україна проводить роботу з поступового імплементування основних документів ОЕСР для наближення стандартів вітчизняного законодавства до новітнього світового рівня. Першими шагами України в цьому напрямку було внесення в Податковий кодекс України [21] статті 39, яка визначила національні правила податкового контролю за трансфертним ціноутворенням. Ці норми були запроваджені 31 вересня 2013 року и постійно оновлюються, зокрема останні зміни до Податкового кодексу України [21] 3 цих питань набрали чинності з 23 травня 2020 року.

Також Україна здійснює й іншу роботу в рамках співпраці з ОЕСР, зокрема, 1 січня 2017 року Україна приєдналася до Плану дій BEPS (від англ. «Base erosion and Profit Shifting) - міжнародного проекту OECP та країн G20 з розробки заходів протидії розмиванню бази оподаткування та виведенню прибутку з-під оподаткування.

Впровадження Плану дій BEPS обумовлене потребою розробити багатосторонній єдиний механізм боротьби 3 агресивним податковим плануванням, спрямованим на штучне зменшення бази оподаткування та переміщення оподатковуваного прибутку до низькоподаткових юрисдикцій. Очікуваним результатом Плану дій BEPS $\epsilon$ встановлення єдиних прозорих податкових правил для всіх країн (юрисдикцій) для того, щоб запобігти ухиленню від сплати податків бізнесом [22].

В рамках Плану дій BEPS розроблено 15 кроків, що покривають різні сфери протидії агресивному податковому плануванню серед яких, активно впроваджуються в Україні:

- вдосконалення правил трансфертного ціноутворення;

- запобігання уникненню від оподаткування за допомогою міжнародних договорів;

- оподаткування доходів контрольованих іноземних компаній;

- обмін інформацією та багато інших.
Головним рекомендаційно-методичним міжнародним документом в галузі податкового регулювання трансфертного ціноутворення $є$ Настанови OЕСР щодо трансфертного ціноутворення для транснаціональних компаній та податкових служб [23], основні норми яких імплементовано в статтю 39 Податкового кодексу України [21].

Слід зазначити, що Настанови ОЕСР щодо трансфертного ціноутворення для транснаціональних компаній та податкових служб [23] це документ, який переглядається та оновлюється для його відповідності сучасній глобальній податковій практиці. Так, наприклад, в 11 лютого 2020 року ОЕСР були прийняті Настанови 3 трансфертного ціноутворення щодо фінансових операцій [24], які було включено до загального тексту Настанов OECP.

Нажаль, норми ст. 39 Податкового кодексу України [21] не містять вичерпні рекомендації щодо застосування трансферного ціноутворення в рамках податкового контролю. Тому дуже часто українські платники податків при визначенні шляхів застосування критеріїв відповідності трансферних цін принципу «витягнутої руки» використовують Настанови ОЕСР щодо трансфертного ціноутворення [23] виходячи 3 власного суб'єктивного розуміння питання. Можливість такого посилання на Настанови ОЕСР зазначалася самими податковими органами [25] навіть незважаючи на те, що Україна не $є$ членом ОЕСР, а тому ці Настанови не можуть розглядатися, як норми прямої дії в Україні.

Податковий контроль за трансферним ціноутворенням грунтується на принципі «витягнутої руки» (Arm's length principle), який $\epsilon$ міжнародним стандартом, погодженим державамичленами ОЕСР та країнами, які не є членами цієї організації (понад 70 країн світу), до яких зокрема, входить Україна. Принцип «витягнутої руки» можна виразити так: прибуток, одержуваний в результаті проведення внутрішньо-групових транзакцій, повинен бути рівнозначним тому, який може бути отриманий від незалежних підприємств за умови відповідності комерційних та/або фінансових умов здійснених ними операцій, а у випадку такої невідповідності збільшення податкових зобов'язань пов'язаних осіб до рівня податкових зобов'язань непов'язаних осіб.

Тобто глобальне та українське податкове законодавство визначає необхідність податкового моніторингу трансферних цін, що застосовуються в рамках внутрішньо-групових операцій, на предмет їх відповідності діючим ринковим показникам. 


\section{Висновки}

Підсумовуючи зазначимо, що трансфертне ціноутворення $\epsilon$ одним 3 найбільш актуальних напрямків досліджень як для управлінського обліку, так й для податкового адміністрування не тільки в Україні, але й в світі. Комплексний погляді на проблему застосування трансферних цін у практиці господарювання через критичний аналіз їх переваг i недоліків для обгрунтування управлінських рішень показав необхідність подальших досліджень щодо вирішення завдань трансфертного ціноутворення в сфері бюджетування, що враховувало би галузеві та організаційно-економічні особливості різних підприємств. Тим більше що необхідність безперервної теоретичної і практичної підтримки такої роботи також пов'язана 3 вимогами податкового законодавства щодо підготовки інформаційного підгрунтя для обгрунтування відповідності трансферних цін принципу «витягнутої руки», які встановлені Податковим кодексом України та Настановами ОЕСР, а також прийняття адекватних ситуаціям управлінських рішень корпораціями як платниками податків.

\section{Література}

1. Атамас П.Й. Управлінський облік: 2-ге вид.: навч. посібник. Київ, Центр учбової літератури, 2009. 440 с.

2. Вахрушина М.А. Бухгалтерский управленческий учет: Учебник для вузов. 2-е изд., доп. и пер. - Москва : ИКФ Омега-Л; Высш. ик., 2002. 528 с.

3. Алборов Р.А. Организаиия учета по иентрам ответственности и трансфертное ценообразование для оченки их деятельности. Экономика сельскохозяйственных $\quad$ u перерабатывающих предприятий. 1999. № 7. С. 35-38.

4. Волков А.И. Трансфертные цены как элемент управления. Управление компанией. 2002. № 2. С. 41

5. Симон Г. Признания мастера ценообразования: как иеена влияет на прибыль, выручку, долю рынка, объем продаж и выживание компании. Москва : Библос, 2017. $199 c$.

6. Палий В.Ф. Современный бухгалтерский учет. М.: Бухгалтерский учет, 2003. 792 c.

7. Радецька Л.П., Овод Л.В. Управлінський облік: навч. посіб. Київ : ВЦ «Академія», 2007. 352 c.

8. Мюллер Г., Гернон Х., Милк Г. Учет: международная перспектива / пер. с англ. 2-е изд., стереотип. Москва : Финансы и статистика, 1996. 652 c.

9. Доунс Дю., Гудман Дюс. Элиот Доунсон vs Портер. Критический анализ на критику моделей Майкла Портера. URL: $\quad$ http://www.franklingrant.ru/ru/news2/data/news_06/2 005_10/20051004_ 174858_yu.asp.pdf (дата звернення: 04.03.2021 р.).

10. Энтони Р., Рис Дж. Учет: ситуаџии и примеры: Пер. с англ. ; Под ред. и $е$ с предисл. А.М. Петрачкова. 2-е изд. Москва : Финансы и статистика, 1996, $560 \mathrm{c}$.

11. ДруриК. Управленческий учет для бизнесрешений. Москва : ЮНИТИДАНА, 2003. 655 c.
12. Eden R., Loren J. Management Control System. R.D. Irwin, 1984. P. 235

13. Sheppard L. Top U.S. tax expert in savage attack on transfer pricing rules. URL: http://taxjustice.blogspot.com/ 2012/08/top-us-tax-expert-in-savage-attack-on.html (dama звернення: 02.03.2021 p.).

14. Hamaekers H. An Introduction to Transfer Pricing the American versus the European Approach. 1995. pp. 1-28. URL: $\quad$ https://repositorio.cepal.org/bitstream/handle/ 11362/34228/S9500513_en.pdf? sequence $=1$ \&isAllowed $=y$ (дата звернення: 02.03.2021 р.).

15. Мімин М. ТЦУ-2020: шо слід врахувати платникам податків? Офіиійне видання державної фіскальної служби Украӥни. 2020. № 21 (1069). URL: http://www.visnuk.com.ua/uk/news/100018362-ttsu-2020scho-slid-vrakhuvati-platnikam-podatkiv

(dama звернення: 02.03.2021 p.).

16. Жукова О.В., Дубницький В. І., Вареня В. О. Трансфертне ціноутворення: український варіант. Київ : Лipa-K, 2014. 184 c .

17. Карпенко І.В. Методика обліку трансфертного ціноутворення на підприсмствах торгівлі. Науковий вісник Ужгородського університету. Серія : Економіка. 2018. Bun. 1. C. 416-424. URL: http://nbuv.gov.ua/UJRN/Nvuuec_2018_1_69 (даma звернення: 20.02.2021 p.).

18. Луиенко I.С. Податковий контроль у сфері трансфертного иіноутворення в Украӥні: сучасна практика. Економіка та держава. 2020. № 7. URL: http://www.economy.in.ua/pdf/7_2020/22.pdf (даma звернення: 20.02.2021 p.).

19. Коблянська О.I. Трансфертне ціноутворення в системі оподаткування Електронне наукове фахове видання з економічних наук «Modern Economics». 2020. № 19. C. 52-57 URL: https://modecon.mnau.edu.ua/issue/192020/koblianska.pdf (дата звернення: 20.02.2021 p.).

20. Офіиійний сайт Організація економічного співробітничтва та розвитку. URL: http://www.oecd.org/about/members-and-partners/ (Jama звернення: 04.03.2021 p.).

21. Податковий кодекс Украӥни : Закон Украӥни від 02.12.2010 № 2755-VI / Верховна Рада Украӥни. URL: https://zakon.rada.gov.ua/laws/show/2755-17 (даma звернення: 04.03.2021 p.).

22. План дій BEPS: ключові аспекти для України. URL: https://mof.gov.ua/storagelfiles/2020_BEPS.pdf (dama звернення: 04.03.2021 p.).

23. Настанова ОЕСР щуодо трансфертного ціноутворення для транснаціональних компаній та податкових служб. 2010. 444 c. URL: https://tax.gov.ua/data/files/253504.pdf (дата звернення: 04.03.2021 p.).

24. Руководство по трансфертному ценообразованию в отношении финансовых сделок (Всеобъемлюющие рамочные механизмы плана BEPS: задачи 4, 8-10, $2020 \quad 54$ c. URL: https://ips.ligazakon.net/document/PFZ00095

25. Офіційний портал Державної податкової служби України. URL: https://tax.gov.ualdiyalnistItransfertne-tsinoutvorenn/zagalnividomosti/\#: : text $=$ B\%20Україні\% 20 норми\%20трансферт 
ного\% 20 іноутворення, $3 \% 2023 \% 20$ травня\%202020\%20ро ку (дата звернення: 04.03.2021 p.).

\section{References}

1. Atamas P.J. Upravlinskyj oblik. Management accounting. K.: Centr uchbovoyi literatury, 2009. 440 p. (in Ukrainian).

2. Vatrushina M.A. (2002) Buhgalterskiy upravlencheskiy uchet. Moskow. IKF Omega-L (in Russian).

3. Alborov R.A. (1999) Organizasiy uheta po centram otvetsvenosti i transvertnoe cenoobrazovanie dliy ocenki ig deiytelnosti. Ekonomika selskochozianstvenich I pererabativauchih predpriatii. Vol. 7 p. 35-38 (in Russian).

4. Volkov A.I. (2002) Transfertnii cheni kak element upravlenia. Upravlenie kompaniei, Vol. 2. P. 41 (in Russian).

5. Simon G. (2017) Priznanie mastera cenoobrazovania: kak cena vliaet na pribil, viruchku, dolu rinka, obiem prodag I vigivanie kompanii. Moskow. Biblos (in Russian).

6. Palii V.F. (2003) Sovremeniy Buhgalterskiy uchet. Moskow. Buhgalterskiy uchet (in Russian).

7. Radeczka L.P., Ovod L.V. Upravlinskyj oblik. Management accounting. K.: VCz "Akademiya", 2007. 352 p. (in Ukrainian).

8. Myuller G., Gernon X., Mylk G. Uchet: mezhdunarodnaya perspektyva. Accounting: An International Perspective. M.: Fynansy i statystyka, 1996. 652 p. (in Russian).

9. Douns J., Gudman J. Elliot. Dounson vs Porter. Kriticheskii analiz na kritiku modeley M. Portera. Available at: http://www.franklin-grant.ru/ru/news2/data/news_06/2 005_10/20051004_174858_yu.asp.pdf (accessed: 04 mars 2021) (in Russian).

10. Entoni R., Ris J. (1996) Uchet: situasii I primeri: Moskow. Finansi I statistika. 560 p. (in Russian).

11. Druri K. (2003) Upravlencheskiy uchet dliy biznespesheniy. Moskow. UNITIDANA, 655 p.

12. Eden R., Loren J. (1984) Management Control System. R.D. Irwin, 235 p.

13. Sheppard, L. (2012), "Top U.S. tax expert in savageattack on transfer pricing rules", available at: http://taxjustice.blogspot.com/2012/08/top-us-tax-expert-in-savageattack-on.html (Accessed: 02 mars 2021).

14. Hamaekers, H. (1995), "An Introduction to Transfer Pricing the American versus the European Approach", pp.128, available

at: https://repositorio.cepal.org/bitstream/handle/11362/34228/S9 500513_en.pdf? sequence $=1 \& \$$ isAllowed $=y \quad$ (Accessed: 02 mars 2021).

15. Mishyn M. (2020) TCO-2020: ho slid vrachovuvaty platnikam podatliv ? Oficiine vidania dergavnoi fiskalnoi slugbi Ukraine, vol. 21 (1069). available at: http://www.visnuk.com.ua/uk /news/100018362-ttsu-2020scho-slid-vrakhuvati-platnikam-podatkiv (Accessed: 02 mars 2021) (in Ukrainian).

16. Gukova O.V., Dubnickiy V.I., Varenia V.O. (2014) Transvertne cenoutvorenia: Ukrainian variant. Kiiv. Lira-K, 184 p. (in Ukrainian).

17. Karpenko I.V. (2018) Metodika obliku Transvertne cenoutvorenia na pidprienstvach torgivly. Scientific Bulletin of Uzhhorod University: Ekonomic. P. 416-424. available at:
http://nbuv.gov.ua/UJRN/Nvuuec_2018_1_69 (Accessed: 20 February 2021) (in Ukrainian).

18. I. Lutsenko (2020) Tax control in the field of transfer pricing in ukraine: current practice. Journal "Ekonomika ta derzhava", vol. 7 available at: http://www.economy.in.ua/pdf/7_2020/22.pdf (Accessed: 20 February 2021) (in Ukrainian).

19. Koblianska Galina (2020) Transfer pricing in the taxation system. The Electronic Scientific Edition on Economics «Modern Economics», vol. 19 p. 52 - 57. available at: https://modecon.mnau.edu.ua/issue/19-2020/koblianska.pdf (Accessed: 20 February 2021) (in Ukrainian).

20. Official website Organization for Economic Cooperation and Development. available at: http://www.oecd.org/about/members-and-partners/ (Accessed: 04 mars 2021).

21. Podatkovyy kodeks Ukrayiny № 2755-VI vid 02.12.2010 r. Zatverdzhenyy Verkhovnoyu radoyu Ukrayiny [Tax Code of Ukraine № 2755-VI of 02.12.2010. Approved by the Verkhovna Rada of Ukraine] Available at: http://zakon4.rada.gov.ua/laws /show/2755-17 [in Ukrainian]. (Accessed: 01 mars 2020).

22. BEPS Action Plan: Key Aspects for Ukraine. available at: https://mof.gov.ua/storage/files/ 2020_BEPS.pdf (Accessed: 01 mars 2021).

23. Nastanovy Orhanizatsiyi ekonomichnoho spivrobitnytstva ta rozvytku shchodo transfertnoho tsinoutvorennya dlya transnatsionalnykh kompaniy ta podatkovykh sluzhb vid 22.07.2010 r. [Guidance Organization for Economic Cooperation and Development on transfer pricing for multinational enterprises and tax authorities on 22.07.2010] Available at: http://minrd.gov.ua/data/material/ 000/021/ 80820/0.pdf [in Ukrainian] (accessed: 04 mars 2021).

24. Transfer pricing guidance on financial transactions OECD (2020) 54 p. Available at: https://ips.ligazakon.net/document /PFZ00095 (accessed: 04 mars 2021).

25. Official website State Tax Service of Ukraine Available at: https://tax.gov.ua/diyalnist-/transfertnetsinoutvorenn/zagalni-vidomosti/\#: : :text=B $\% 20$ Україні\%20норми\%20трансфертного\%20ціноутворення,3 \%2023\%20травня\%202020\%20року (accessed: 04 mars 2021).

Рецензент: д-р екон. наук, професор Момот Т.В. Харківський національний університет міського господарства імені О.М. Бекетова, Україна.

\section{Автор: ВЛАСОВА Олена Свгенівна}

кандидат економічних наук, доцент, доцент кафедри фінансово-економічної безпеки, обліку $i$ aудиту

Харківський національний університет міського господарства імені О.М. Бекетова

E-mail: helenevlasova@gmail.com

ID ORCID: https://orcid.org/0000-0003-0022-9721 


\title{
TRANSFER PRICES: PREREQUISITES FOR USE IN MANAGEMENT ACCOUNTING AND TAX ADMINISTRATION
}

\author{
O. Vlasova
}

O.M. Beketov National University of Urban Economy in Kharkiv, Ukraine

Today, the issues of transfer pricing come to the fore in the ranking of current problems of tax administration not only in Ukraine but also in the world as a whole. This is due to the need for tax control to ensure price equality between related and independent entities in international business as a measure to combat the erosion of the tax base and the withdrawal of profits from taxation. The article presents a structured analysis of research by foreign and domestic scientists on transfer pricing in the field of management accounting or tax control. In particular, the grouping of views of scientists and practitioners on the nature and role in the accounting and analytical system of transfer pricing from the point of view of management accounting and tax administration. Study of the impact on the practice of transfer pricing methods of the picture of economic reality distorted by the negative impact of the COVID-19 pandemic. The need to use the transfer pricing mechanism in management accounting is due to the current trend of decentralization of management, and a prerequisite - the desire of top management to accelerate the production process, accelerate the turnover of equity and maximize profits. The advantages of using transfer pricing in management accounting to accelerate the production process and maximize profits, which led to the creation of corporations with the final technological cycle. It is also established that when deciding on the use of such a tool of internal pricing, one should keep in mind the cautions analyzed in the article. The preconditions for the introduction of tax control over transfer pricing in international business, as well as the basic laws and regulations in force in the global and Ukrainian economic space. The necessity and validity of the application of the OECD International Guidelines on Transfer Pricing, despite the provisions of Art. 39 of the Tax Code of Ukraine The ways of further development of tax control over transfer pricing within the framework of the BEPS Action Plan in Ukraine are considered. The need for further research on solving the problems of transfer pricing in the field of management accounting and taxation was identified, especially on the preparation of an information basis to justify the compliance of transfer prices with «Arm's length principle».

Keywords: transfer pricing, management accounting, tax control, domestic business operations, international business. 